\title{
HISTÓRIA DO TEMPO PRESENTE E A MEMÓRIA DE TRABALHADORAS JAGUARENSES
}

\author{
HISTORIA DEL TIEMPO PRESENTE Y MEMORIA DE TRABAJADORAS \\ DE YAGUARON
}

\author{
${ }^{1}$ Kênya Jessyca Martins de Paiva \\ ${ }^{1}$ kenya.paiva@ hotmail.com, Universidade do Estado de Santa Catarina.
}

\begin{abstract}
RESUMO
Neste trabalho busco relacionar a história do tempo presente com o tema da minha pesquisa que é a história das trabalhadoras da pesca do Município de Jaguarão, situado no sul do Rio Grande do Sul e que faz fronteira com a cidade uruguaia, Rio Branco. O intuito da investigação é discutir a partir de entrevistas e outras fontes que elucidaram as memórias de algumas das trabalhadoras, a relação delas com seu espaço de trabalho para perceber seus saberes, suas vivências e a toda uma gama de conhecimentos forjados no cotidiano, sob o recorte de 1980 até os dias atuais. Como a pesquisa esta em fase inicial, a proposta neste momento será de refletir sobre a trajetória historiográfica, limites e possibilidades da pesquisa com o marco temporal do presente.
\end{abstract}

PALAVRAS-CHAVE: História, Tempo Presente, Memória.

\section{RESUMEN}

En este trabajo busca relacionar la historia de este tiempo con el tema de mi investigación es la historia de los trabajadores en el municipio pesquero de Yaguarón, ubicado en el sur de Río Grande do Sul y limítrofe con la ciudad uruguaya de Río Branco. El objetivo de la investigación es analizar las entrevistas y otras fuentes que dilucidarán los recuerdos de algunos de los trabajadores, su relación con su espacio de trabajo para darse cuenta de sus conocimientos, sus experiencias y toda la gama de conocimientos forjado en la vida cotidiana, en la cosecha de 1980 hasta nuestros días. Como la investigación en esta fase inicial, la propuesta ahora es reflexionar sobre las tendencias historiográficas, límites y posibilidades de la investigación con el marco temporal de este.

PALABRAS CLAVE: Historia, actualidad, memoria.

A contemporaneidade é o marco temporal da minha pesquisa, dessa maneira, Chaveau e Tétart (1999, p. 16) nos fazem pensar sobre a presença física no nosso tempo e no nosso tema, isso não pode ser deixado de lado, pois é preciso nos reconhecer como sujeitos históricos do nosso tempo. Na investigação meu objetivo é relacionar a memória e o presente histórico através de relatos que serão realizados com pescadoras no Município de Jaguarão/RS, assim como, atas e outros documentos do Sindicato de Pescadoras e Pescadores. Utilizarei como metodologia a História oral, umas das abordagens que têm oportunizado crescente inserção das camadas populares e "invisíveis", a partir de suas próprias vozes, na História do Tempo Presente. Com a oralidade têm sido possível registrar narrativas que trazem em si uma vasta potencialidade interpretativa e são instrumentos importantes de construção de memórias individuais e coletivas, frente ao fenômeno que a modernização esta causando nas sociedades ocidentais com aquilo que Andreas Hyussen, (2000, p. 33) chamou de cultura da memória. Nesse sentido, a proposta é utilizar principalmente as memórias de oito a dez trabalhadoras como documentos de análise que contribuirão para reconhecer e situá-las na micro e na macro história. 


\section{Memória e Tempo Presente: Breve contextualização}

O contexto da $2^{\text {a }}$ Guerra Mundial auxiliou na emergência de diversas discussões historiográficas, nas quais, as experiências do contemporâneo passaram a estar entre os interesses não só de historiadores, mas de jornalistas, cientistas sociais e políticos, tendo como influência o que Riox (1999, p. 46) chamou de "impaciência social" por respostas aos acontecimentos da época. Nesse momento, a memória ganha um papel de destaque na medida em que passa a ser um instrumento de controle e domínio, a partir da supressão de vestígios, intimidação, eufemismos e propaganda segundo Todorov (2002, p. 135 - 138), servindo com isso para legitimação de territórios, identidades, discursos políticos, posturas e ideologias.

A expressão "História do tempo presente", de acordo com Pierre Lagrou (2009, p. 4), foi introduzida na França no final dos anos 1970 por uma nova escola que tinha como objetivo se diferenciar historiograficamente da que estudava o século XIX. Havia um grande desprezo por parte da elite intelectual que colocava os fatos recentes como inferiores e de alcance impossível, abrindo espaço para diferentes questionamentos acerca da legitimidade ou não que o estudo histórico do recente exerceria. Nesta sociedade atual, marcada pelo consumo desenfreado e pela notoriedade da memória, essas visões que outrora tentaram descaracterizar o estudo do tempo presente foram revisadas e de certa maneira superadas. Sabe-se que a História do Tempo presente é uma modalidade importante porque serve para colocar a história mais próxima em evidência no processo histórico. Os historiadores estão sendo pressionados a ter uma reação a essa perspectiva moderna de rememorar e descartar tudo a todo o momento e têm a tarefa de construir sentido para isso, pensando nas temporalidades ocorridas nos processos que estão sendo ressignificados a todo instante.

François Dosse (2012, p. 6) compreende que a História do Tempo Presente têm uma singularidade própria, pois além de estar na "intersecção do presente e da longa duração", ela reside na "contemporaneidade do não contemporâneo". Para Dosse, o tempo presente equivale a um meio-termo entre passado e presente e por isso invoca uma nova concepção para o fazer histórico. Essa nova concepção é marcada pela diferença da História do Tempo Presente para as demais temáticas históricas que é o nosso envolvimento com o presente no qual vivemos e estudamos. Para Chaveau e Tétart (1999, p. 27) a História Presente exige um posicionamento frente aos acontecimentos que estão em andamento e ao retirar o historiador do seu esconderijo no passado, provoca-o a retomar sua função pública que é interpretar criticamente e desnaturalizar as verdades absolutas e simplistas.

De acordo com o historiador francês François Hartog (1996, p. 261) o interesse voltado aos vestígios do passado seria uma das consequências do Regime de Historicidade Presentista, que a partir de 1970 transformou o modo de nos relacionarmos com o tempo. Agora não é mais o passado quem tem a chave de todas as portas, e sim o presente, por isso o crescente apelo pela memória e pelo patrimônio. Após a Revolução Industrial - século XIX a sociedade do presente supera as coisas do passado, isto é, altera-se a estrutura de modo a fazer com que desta vez esteja o futuro no horizonte de expectativa (KOSELLECK, 2006, p. $33)$.

Toda essa nova forma de se relacionar com a temporalidade passou a exigir dos historiadores uma narrativa adequada que não se limita a ser totalmente objetiva, isto é, que permita transparecer a subjetividade pertencente em todos os seres humanos, mas que num determinado momento nos foi negada com tanta veemência. Conforme Sabina Loriga (2012, p. 254), "o historiador não deve apagar sua subjetividade como queria Ranke, ele deve aprender a reconhecê-la e a transformá-la em fonte de conhecimento". O reconhecimento da "boa subjetividade" faz com que os historiadores compartilhem e enxerguem seus lugares de fala, percebendo que a contemporaneidade é uma experiência em processo. 


\section{Resultados esperados}

Considerando o desafio historiográfico do século XXI que é romper com as categorias coloniais que universalizam o olhar e a produção histórica das sociedades, o intuito de refletir sobre as trabalhadoras da pesca de Jaguarão na dissertação veio de uma inquietação da vida presente que está inserida no âmbito das experiências vividas por mim em Jaguarão, relacionada à busca de conhecer e analisar o passado/presente de populações subalternizadas e grupos sociais - neste caso as mulheres - marginalizadas na História dita oficial. Deste modo, a ansiedade é por reflexões que ultrapassem categorias que são usadas para pensar todas as sociedades de forma homogênea. Já que uma das provocações que o campo da História do Tempo Presente traz a nós historiadores é exatamente a de nos fazer compreender que é preciso inovar para "sair do mesmo" nos debates e interpretações dos documentos.

\section{Referências}

CHAUVEAU, Agnès; TÉTART, Philippe. Questões para a história do presente. Bauru: EDUSC, 1999.

DOSSE, François. História do tempo presente e historiografia. Florianópolis, v. 4, n. 1, p. 5 22, jan-jun. 2012.

HARTOG, François. "Regimes de Historicidade. Presentismo e Experiências do Tempo". Belo Horizonte: Editora Autêntica, 2013.

HUYSSEN, Andreas. Seduzidos pela memória: arquitetura, monumentos, mídia. Rio de Janeiro: Aeroplano, 2000.

LAGROU, Pierre. A História do Tempo Presente na Europa depois de 1945 - Como se constituiu e se desenvolveu um novo campo disciplinar Rio de Janeiro: Revista Eletrônica Boletim do TEMPO, Ano 4, Nº15, Rio, 2009 [ISSN 1981-3384]

LORIGA, Sabrina. O eu do historiador. História da historiografia. Revista História e Historiografia, Ouro Preto, n. 10, p. 247-259, dezembro/2012.

RIOUX, Jean-Pierre. Pode-se fazer uma história do presente? In: CHAUVEAU, A., TÉTART, P. (orgs.). Questões para a história do presente. Bauru, SP: EDUSC, 1999.

TODOROV, TZVETAN. Memória do mal, tentação do bem. Indagações sobre o século XX. São Paulo: ARX, 2002. 